•KOSnเn" JIK. Vol. 7 No. 1 Mei 2019

\title{
HUBUNGAN TINGKAT KECEMASAN DENGAN MOTIVASI KERJA PERAWAT DI RSUD dr. SOERATNO GEMOLONG
}

\author{
Dinar Ariasti ${ }^{1}$, Artha Tri Handayani ${ }^{2}$
}

\begin{abstract}
Background: Anxiety is something that is naturally experienced by every human being. Not a few people who experience anxiety when carrying out their work. High workloads, a risky work environment and high professional demands create a lot of pressure faced by individuals while working. Based on the results of interviews with three nurses in the internal medicine room, many expressed their enthusiasm for working to decline. This happens because of concerns about contracting diseases experienced while working and benefits that have not been fulfilled.

The purpose: This study was to determine the relationship between anxiety level and work motivation of nurses in the Internal Medicine Room of the RSUD Dr. Soeratno Gemolong.

The subjects The population in this study were nurses who served in the internal medicine room of the RSUD dr. Soeratno Gemolong Sragen is in Teratai and Tulip room, which consists of 32 nurses.

Methods: This research use correlation research design with a cross sectional method approach. The data collection tool used is a questionnaire to measure the level of anxiety and work motivation of nurses at Dr. Soeratno Gemolong Sragen.

The results of the study: there were 26 respondents (81.25\%) had mild anxiety levels, 5 respondents $(15.62 \%)$ had moderate anxiety levels and 1 respondent $(3.13 \%)$ had severe anxiety levels. Found 18 people $(56.25 \%)$ had moderate work motivation, 11 people $(34.38 \%)$ had high work motivation and 3 respondents $(9.37 \%)$ had low work motivation. The results of the test using Rank Spearman SPSS version 18.0 program with $\alpha=1 \%(0.01)$ obtained the number of correlation coefficients $(r)=0.552$ which means that the level of correlation is strong between variables of anxiety level with work motivation. The results of the significance values for this study were $0.001 \quad(\alpha<0.05)$ which can be interpreted as having a significant relationship between the level of anxiety and work motivation.

The conclusion of this study: there is a a relationship between the level of anxiety and work motivation in Dr. Soeratno Gemolong Hospital Sragen.
\end{abstract}

Keywords: level of anxiety, work motivation

\section{PENDAHULUAN}

Kecemasan merupakan sesuatu yang wajar dialami setiap manusia. Tidak sedikit juga orang yang mengalami kecemasan saat menjalankan pekerjaannya. Beban kerja yang tinggi, lingkungan pekerjaan beresiko dan tuntutan profesionalitas yang tinggi menimbulkan banyak tekanan yang dihadapi individu saat bekerja. Hal ini dapat menurunkan motivasi dan semangat saat menjalankan pekerjaanya.

Menurut Rochman (2010:104), kecemasan merupakan suatu

perasaan subjektif mengenai
ketegangan mental yang
menggelisahkan sebagai reaksi
umum dari ketidakmampuan
mengatur masalah atau tidak
adanya rasa aman. Perasaan tidak
menentu tersebut pada umumnya
tidak menyenangkan yang nantinya
akan menimbulkan perubahan
fisiologis dan fisik.
Hasil penelitian Wijayanti (2017)
dengan judul "Hubungan antara
Kecemasan dengan Prestasi Kerja
Karyawan PT. Kusumahadi
Santosa Karanganyar dengan


responden 50 karyawan PT. Kusumahadi Santosa menunjukkan hasil analisis data bahwa ada hubungan negatif yang sangat signifikan antara kecemasan dengan prestasi kerja dengan koefisien korelasi $r(x y)=0,637 ; p=$ $0,000 \quad(p<0,01)$ artinya ada hubungan positif yang sangat signifikan antara kecemasan dengan prestasi kerja. Penelitian yang dilakukan Widodo, et al (2017) pada 100 mahasiswa yang mengambil mata kuliah matematika tahun akademik 2013/2014 menunjukkan hasil nilai t observasi (t obs ) sebesar -6,477 dengan nilai probabilitas sig sebesar 0,000 . Karena diperoleh nilai probabilitas sig kurang dari 0,05 dapat disimpulkan bahwa ada hubungan antara tingkat kecemasan terhadap motivasi belajar mahasiswa pada mata kuliah matematika tahun akademik 2013 -2014. Dua penelitian tersebut menunjukkan hasil bahwa terdapat hubungan antara kecemasan dengan prestasi kerja dan motivasi belajar.

Menurut Sobur (2011:280) faktorfaktor yang mempengaruhi kepuasan kerja disebut motivator ini meliputi prestasi, penghargaan, tanggung jawab, kemajuan atau promosi, pekerjaan itu sendiri dan potensi bagi pertumbuhan pribadi. Faktor-faktor yang berkaitan dengan ketidakpuasan adalah faktor pemeliharaan atau kesehatan, gaji, pengawasan, keamanan kerja, kondisi kerja, administrasi, kebijakan organisasi, dan hubungan antar pribadi dengan rekan kerja, atasan dan bawahan di tempat kerja. Apabila faktorfaktor tersebut tidak ada di tempat kerja, pegawai akan kekurangan motivasi.

Sumber daya manusia (SDM) merupakan aset dari sebuah tempat kerja yang paling mahal dibanding dengan aset-aset lain karena sumber daya manusia merupakan penggerak utama organisasi tempat kerja tersebut. Sumber daya manusia harus dikelola secara optimal, continue dan diberi ekstra perhatian dan memenuhi hak-haknya. Selain itu sumber daya manusia adalah patner dari sebuah tempat kerja untuk mencapai tujuan organisasi. Tenaga keperawatan merupakan suatu komponen SDM rumah sakit sekaligus merupakan anggota tim kesehatan garda depan yang berperan dalam menghadapi masalah kesehatan pasien selama 24 jam secara terus-menerus (Cahyani, Wahyuni dan Kurniawan, 2016).

Tenaga profesional perawat merupakan sumber daya manusia terbesar yang ada di lingkungan rumah sakit yang memberikan pelayanan kesehatan kepada pasien. Tenaga perawat berisiko tinggi terinfeksi kuman ataupun tertular berbagai macam penyakit. Perawat merupakan tenaga kesehatan di garis terdepan yang selama 24 jam berinteraksi dengan pasien dalam memberikan asuhan keperawatan (Elvia, 2013). Resiko tertular penyakit dari pasien ini dapat menimbulkan kecemasan pada perawat. Hasil penelitian Efstathiou, et al, (2011) yang berjudul Factors Influencing Nurses' Compliance with Standard Precautionsin Orderto Avoid Occupational Exposureto Microorganisms : a Focus Group Study dengan subyek penelitian 32 perawat di dua rumah sakit umum di Cyprus menunjukkan adanya ketakutan pada responden setiap kali membayangkan kemungkinan terinfeksi oleh penyakit saat mempraktikkan tugas keperawatannya.

Kondisi fisik lingkungan tempat kerja dimana para pekerja beraktifitas sehari-hari mengandung banyak bahaya, langsung maupun tidak langsung bagi keselamatan 
dan kesehatan pekerja. Resiko bahaya yang dihadapi tenaga kerja adalah bahaya kecelakaan kerja serta penyakit akibat kerja yang diakibatkan karena kombinasi dari berbagai faktor seperti tenaga kerja, peralatan kerja dan lingkungan kerja (Sucipto, 2014:15). Tenaga perawat kemungkinan melakukan kontak dengan cairan darah berkuman, cairan tubuh, urin, kotoran manusia dan muntahan yang mengandung kuman penyakit sehingga resiko tertular penyakit tinggi. Resiko tersebut menimbulkan kecemasan pada perawat yang bekerja diruang beresiko tertular penyakit seperti ruang penyakit dalam.

Kecemasan saat bekerja dapat menurunkan motivasi perawat sehingga kinerja perawat menjadi kurang baik. Berdasarkan hasil penelitian yang dilakukan oleh Ramadini dan Jasmita (2015) didapatkan bahwa dari 17 orang perawat pelaksana yang memiliki motivasi rendah berdasarkan kebutuhan keamanan terdapat $88,2 \%$ memiliki kinerja kurang baik dan 23 orang perawat pelaksana yang memiliki motivasi tinggi berdasarkan kebutuhan keamanan terdapat $69,6 \%$ memiliki kinerja baik. Hasil uji statistik menggunakan uji Chi-Square didapatkan nilai $p$ value $=0,001(p$ value $<0,05$ ) artinya terdapat hubungan yang bermakna antara motivasi berdasarkan kebutuhan keamanan dengan kinerja perawat pelaksana di Ruangan Rawat Inap RSUD dr. Rasidin Padang tahun 2014.

Jumlah perawat di ruang Teratai dan Tulip RSUD dr. Soeratno Gemolong adalah 32 perawat tetap. Berdasarkan hasil wawancara dengan tiga perawat di ruang penyakit dalam menyatakan banyak yang mengungkapkan semangat untuk bekerja menurun. Hal ini terjadi karena kekhawatiran untuk tertular penyakit yang dialami saat bekerja di ruang perawatan dengan beberapa pasien dengan gangguan penyakit seperti TBC, hepatitis dan HIV AIDS walaupun sudah dilengkapi dengan alat pelindung diri. Beberapa perawat menginginkan untuk rotasi ruangan ke ruangan lain dengan resiko yang lebih rendah. Beberapa perawat juga mengeluhkan gaji atau tunjangan yang belum sesuai dengan kebutuhan dan beban kerja.

Berdasarkan uraian di atas maka penulis tertarik untuk melakukan penelitian dengan judul "Hubungan Tingkat Kecemasan dengan Motivasi Kerja Perawat di Ruang Penyakit Dalam RSUD dr. Soeratno Gemolong".

Perbedaan dengan penelitian sebelumnya adalah pada salah satu variabel, responden dan lokasi penelitian yaitu di rumah sakit umum daerah kabupaten. Penelitian ini membahas tentang kaitan kecemasan dengan motivasi kerja perawat yang bekerja di ruang penyakit dalam atau ruangan yang beresiko tinggi terjadi penularan penyakit.

\section{DESAIN PENELITIAN}

Pada penelitian ini menggunakan desain penelitian korelasi dengan pendekatan metode cross sectional untuk mengetahui hubungan antara tingkat kecemasan dengan motivasi perawat di ruang penyakit dalam RSUD dr. Soeratno Gemolong Sragen.

\section{POPULASI, SAMPEL, DAN TEKNIK SAMPLING}

Populasi pada penelitian ini adalah perawat yang berdinas di ruang penyakit dalam RSUD dr. Soeratno Gemolong Sragen yaitu di ruang Teratai dan Tulip yang berjumlah 32 perawat.

Dalam penelitian ini peneliti mengambil semua populasi yang 
ada untuk dijadikan sampel, yaitu seluruh perawat yang berdinas di ruang penyakit dalam RSUD $\mathrm{dr}$. Soeratno Gemolong Sragen.

Dalam penelitian ini, peneliti menggunakan teknik total sampling atau seluruh populasi dijadikan sampel.

Pada penelitian yang berjudul "Hubungan Kecemasan dengan Motivasi Perawat di Ruang Penyakit Dalam RSUD dr. Soeratno Gemolong", instrumen penelitiannya dapat diuraikan sebagai berikut:

1. Variabel bebas yaitu kecemasan pada perawat di ruang penyakit dalam RSUD dr. Soeratno Gemolong. Penilaian kecemasan menggunakan alat ukur baku yaitu HRSA, terdiri atas 14 item, masing-masing item jika didapatkan nilai 0 berarti tidak ada gejala sama sekali, nilai 1 berarti terdapat satu dari gejala yang ada, nilai 2 separuh dari gejala yang ada, nilai 3 lebih dari separuh gejala yang ada, nilai 4 semua gejala yang ada. Sehingga skor minimal 0 dan maksimal 56 (14 $\mathrm{x}$ 4). 0 - 19 berarti kecemasan ringan, $20-38$ berarti kecemasan sedang dan 39-56 berarti kecemasan berat.

2. Variabel terikat: motivasi perawat, diperoleh dengan memberikan beberapa pertanyaan kepada perawat tentang motivasi. Responden diminta mengisi atau menjawab pertanyaaan yang berisi 20 pertanyaan dengan pilihan jawaban sangat setuju $=5$, setuju $=4$, kurang setuju $=3$, tidak setuju $=2$ dan sangat tidak setuju=1. Penilaian skor 133=motivasi rendah, skor 34$67=$ motivasi sedang, skor 68 $100=$ motivasi tinggi .

Dalam penelitian ini, alat pengumpulan data yang digunakan adalah kuesioner untuk mengetahui hubungan tingkat kecemasan dan motivasi kerja perawat di RSUD dr. Soeratno Gemolong Sragen. Pengelolaan data dilakukan dengan proses editing, koding, tabulating, dan skoring. Dalam penelitian ini dilakukan analisa bivariat pada kecemasan dengan motivasi. Data yang sudah terkumpul dianalisa dengan menggunakan Uji Rank Spearman dengan program SPSS seri 18 untuk menganalisis apakah ada hubungan pada penelitian tersebut.

\section{HASIL PENELITIAN}

Penelitian dilakukan di RSUD dr. Soeratno Gemolong Sragen dengan responden 32 perawat yang berdinas di ruang penyakit dalam Teratai dan Tulip pada bulan Desember 2018 sampai dengan Januari 2019.

Di bawah ini akan dipaparkan hasil penelitian tentang hubungan tingkat kecemasan dan motivasi kerja perawat di RSUD dr. Soeratno Gemolong Sragen.

Tabel 1.

Distribusi Frekuensi Responden

\begin{tabular}{ccc}
\hline Karakteristik & $f$ & $\%$ \\
\hline Kelompok Umur & & \\
$21-30$ & 24 & 75 \\
$31-40$ & 6 & 18,75 \\
$41-50$ & 2 & 6,25 \\
Tingkat Pendidikan & 1 & 3,12 \\
SPK & 27 & 84,38 \\
D3 & 4 & 12,5 \\
S1 & & \\
Jenis Kelamin & 6 & 18,75 \\
Laki-laki & 26 & 81,25 \\
Perempuan & & \\
\hline
\end{tabular}

Tabel 1 diperoleh informasi bahwa sebagian besar responden berjumlah 24 responden (75\%) berada pada kelompok umur 21-30 tahun dan jumlah responden paling sedikit 2 responden $(6,25 \%)$ berada 
pada kelompok umur 41-50 tahun. Tingkat pendidikan sebagian besar responden adalah D3 Keperawatan sebesar 27 responden (84,38\%). Jenis kelamin sebagian besar adalah perempuan sejumlah 26 responden $(81,25 \%)$.

Tabel 2

Distribusi Frekuensi Tingkat Kecemasan dan Motivasi Kerja Perawat di RSUD dr. Soeratno Gemolong

\begin{tabular}{ccc}
\hline Variabel & $\mathrm{f}$ & $\%$ \\
\hline Tingkat Kecemasan & & \\
Ringan & 26 & 81,25 \\
Sedang & 5 & 15,62 \\
Berat & 1 & 3,13 \\
Motivasi Kerja & & \\
Perawat & & \\
Rendah & 3 & 9,37 \\
Sedang & 8 & 56,25 \\
Tinggi & 11 & 34,38 \\
\hline Jumlah & 32 & 100 \\
\hline
\end{tabular}

Dari tabel di atas ditemukan ada 26 responden $\quad(81,25 \%) \quad$ yang merupakan sebagian besar responden mempunyai tingkat kecemasan ringan, 5 responden $(15,62 \%)$ mempunyai tingkat kecemasan sedang dan 1 responden $(3,13 \%)$ mempunyai tingkat kecemasan berat. Ditemukan sebagian besar responden yaitu sejumlah 18 orang $(56,25 \%)$ mempunyai motivasi kerja tingkat sedang, 11 orang $(34,38 \%)$ mempunyai motivasi kerja tinggi dan paling sedikit 3 responden $(9,37 \%)$ mempunyai motivasi kerja rendah.
Tabel 4

Tabulasi Silang Hubungan Tingkat Kecemasan dengan Motivasi Kerja Perawat di RSUD Dr. Soeratno Gemolong

\begin{tabular}{|c|c|c|c|c|}
\hline \multirow{2}{*}{ Kecemasan } & \multicolumn{3}{|c|}{ Motivasi Kerja } & \multirow{2}{*}{$p$} \\
\hline & Renda & edar & Tinggi & \\
\hline Ringan & 0 & 15 & 11 & \\
\hline Sedang & 2 & 3 & 0 & 0,001 \\
\hline Berat & 1 & 0 & 0 & \\
\hline Jumlah & 3 & 18 & 11 & 3 \\
\hline
\end{tabular}

Dari tabel di atas peneliti menemukan bahwa :

1. Terdapat 15 responden dengan tingkat kecemasan ringan memiliki tingkat motivasi kerja sedang dan 11 responden memiliki tingkat motivasi kerja tinggi.

2. Terdapat 2 responden dengan tingkat kecemasan sedang memiliki tingkat motivasi kerja rendah dan 3 responden memiliki tingkat motivasi kerja sedang.

3. Terdapat 1 responden dengan tingkat kecemasan berat memiliki tingkat motivasi kerja rendah.

Dari hasil penelitian hubungan tingkat kecemasan dengan motivasi kerja perawat di ruang penyakit dalam RSUD Dr. Soeratno Gemolong diperoleh hasil uji menggunakan Rank Spearman program SPSS versi 18.0 dengan a $=1 \%(0.01)$ diperoleh angka koefisen korelasi $(r)=0,552$ yang berarti tingkat korelasi kuat antara variabel tingkat kecemasan dengan motivasi kerja. Hasil nilai signifikansi untuk penelitian ini adalah $0,001(\alpha<0,05)$ yang dapat diartikan ada hubungan yang signifikan antara tingkat kecemasan dengan motivasi kerja. 


\section{PEMBAHASAN}

Dari hasil tabel 2 dapat dicermati bahwa dari tabel di atas ditemukan 26 responden $(81,25 \%)$ atau sebagian besar responden mempunyai tingkat kecemasan ringan, 5 responden $(15,62 \%)$ mempunyai tingkat kecemasan sedang dan 1 responden (3,13\%) mempunyai tingkat kecemasan berat. Responden dengan tingkat kecemasan berat dan sedang mengungkapkan adanya gejala kecemasan seperti gangguan jantung berdebar-debar, susah tidur, perasaan depresi, sulit konsentrasi, bingung dan tegang. Responden dengan tingkat kecemasan ringan mengungkapkan adanya rasa khawatir dan gangguan seperti bingung dan tegang saja. Hal ini seperti yang dikemukakan oleh Hawari (2011: 66-67) yang menyatakan bahwa orang dengan tipe kepribadian pencemas tidak selamanya mengeluh hal-hal yang sifatnya psikis saja, tetapi sering juga disertai dengan keluhan-keluhan fisik seperti merasa tegang, gelisah, gangguan pola tidur, gangguan konsentrasi dan daya ingat, rasa sakit pada tulang, berdebar-debar, sesak nafas dan gangguan pencernaan. Apabila kekhawatiran sudah disertai tanda-tanda atau gangguan fisik dan emosi yang intensif seperti, keluar keringat dingin, jantung berdebar-debar, tidak bisa tidur, gelisah, tekanan darah naik dan sebagainya maka kekhawatiran itu bisa digolongkan dalam kecemasan dan apabila terus berlanjut (kronis) bisa menimbulkan fatique atau kelelahan mental (depresi) sehingga mengganggu aktivitas sehari-hari (Prawiroharjo, 2014: 251). Kecemasan yang berlarutlarut akan banyak juga menimbulkan gangguan-gangguan psikologi maupun penyakit fisik (Priyoto 2015 : 25). Senada dengan penelitian yang dilakukan oleh Lestari, Wihastuti dan Rahayu (2013) yang berjudul "Hubungan Tingkat Kecemasan dengan Tingkat Kemandirian Activities Of Daily Living (ADL) pada Lanjut Usia di Panti Werdha" dengan hasil $p$ value $=0,000<0,05$ sehingga dapat diambil kesimpulan bahwa hipotesis penelitian $(\mathrm{H} 1)$ diterima, artinya terdapat hubungan yang signifikan antara tingkat kecemasan dan tingkat kemandirian pada Lansia. Hal ini berarti semakin tinggi tingkat kecemasan semakin rendah tingkat kemandirian $\mathrm{ADL}$ pada Lansia, begitu pula sebaliknya semakin tinggi tingkat kemandirian ADL semakin rendah tingkat kecemasan pada Lansia.

Sejumlah $84,37 \%$ responden mengungkapkan tunjangan yang diperoleh belum memuaskan dan sejumlah $65,62 \%$ responden mengungkapkan kondisi lingkungan kerja yang kurang aman dan belum dikelola dengan baik sehingga menimbulkan beban pikiran saat bekerja. Seperti yang diungkapkan oleh Kozier, et al (2010, 539) perawat seperti halnya klien, rentan untuk mengalami ansietas dan stres. Praktik keperawatan mencakup banyak stressor yang berhubungan dengan klien dan lingkungan kerja, seperti jumlah staf yang kurang memadai, peningkatan keparahan penyakit klien dan dukungan yang tidak adekuat. Meskipun kebanyakan perawat dapat menghadapi tuntutan fisik dan emosi keperawatan secara efektif, pada beberapa situasi perawat menjadi kewalahan dan mengalami keletihan fisik dan mental. Hal ini sejalan dengan penelitian yang dilakukan oleh Rizky dan Afrianty (2018) yang berjudul "Pengaruh Beban Kerja terhadap Stres Kerja dengan Work Life Balance sebagai Variabel Intervening (Studi Pada Dinas Sosial Provinsi Jawa Timur 
Surabaya)" dengan hasil penelitian t hitung sebesar 2,936 dan nilai sig. sebesar $0,005 \quad(p<0,05)$, sehingga beban kerja memberikan pengaruh yang tinggi terhadap stres kerja. Hal ini berarti semakin meningkatnya beban kerja akan memberikan peningkatan terhadap stres kerja.

Hasil penelitian tentang motivasi kerja perawat di RSUD Dr. Soeratno Gemolong Sragen seperti yang tercantum dalam tabel 4 ditemukan sebagian besar responden sejumlah 18 orang $(56,25 \%)$ mempunyai motivasi kerja tingkat sedang, 11 orang $(34,38 \%)$ mempunyai motivasi kerja tinggi dan paling sedikit 3 responden $(9,37 \%)$ mempunyai motivasi kerja rendah. Beberapa responden mengungkapkan bahwa pemenuhan kebutuhan fisiologis sebagai faktor utama untuk bekerja dan terdapat beberapa responden yang menyatakan bahwa bekerja di rumah sakit memudahkan untuk melakukan pemeriksaan kesehatan saat mereka sakit atau ada keluarga yang sakit dengan jaminan kesehatan. Seperti yang diungkapkan oleh Donsu (2017:233) secara individual motivasi seseorang sangatlah personal satu dan lainnya berbeda. Mereka menempatkan dan mendasarkan atas nilai-nilai tertentu sesuai dengan pandangan dan dasar hidupnya. Meskipun demikian secara mendasar atau hakiki, tujuan motivasi siapapun adalah untuk mendapatkan sesuatu atau terhindar dari sesuatu.

Pada penelitian ini lebih dari 84,37 $\%$ responden mengungkapkan gaji yang mereka terima tidak sesuai dengan beban kerja dan lebih dari $65,62 \%$ responden menyatakan bahwa kondisi lingkungan kerja belum memenuhi syarat keamanan. Dalam Sobur (2011: 281) mengungkapkan bahwa faktorfaktor yang mempengaruhi kepuasan kerja meliputi prestasi, penghargaan, tanggung jawab, kemajuan atau promosi, pekerjaan itu sendiri dan potensi bagi pengembangan pribadi. Sedangkan faktor-faktor yang berkaitan dengan ketidakpuasan disebut faktor pemeliharaan (maintenance) atau kesehatan (hygiene), gaji, pengawasan, keamanan kerja, kondisi kerja, administratif, kebijakan organisasi dan hubungan antar pribadi. Apabila faktor-faktor tersebut tidak ada, pegawai akan merasa tidak puas. Senada dengan penelitian yang dilakukan oleh Aswat (2010) dengan judul faktorfaktor yang berhubungan dengan motivasi kerja perawat di unit rawat inap RSUD Puri Husada Tembilahan Riau dengan hasil uji statistik didapatkan nilai $p$ value adalah 0,039, ini berarti bahwa pada alpha 0,05 terlihat ada hubungan yang signifikan antara persepsi terhadap gaji yang diterima dengan motivasi kerja perawat. Seperti halnya penelitian yang dilakukan oleh Cahyani, Wahyuni dan Kurniawan (2016) dengan hasil terdapat hubungan antara kondisi kerja dengan motivasi kerja pada perawat di rumah sakit jiwa RSJD Dr. Amino Gondohutomo Provinsi Jawa Tengah dengan nilai $p$ value $=0,002$ $(p<0,05)$.

Dari hasil penelitian hubungan tingkat kecemasan dengan motivasi kerja perawat di ruang penyakit dalam RSUD Dr. Soeratno Gemolong diperoleh hasil uji menggunakan Rank Spearman program SPSS versi 18.0 dengan diperoleh angka koefisen korelasi $(r)=0,552$ yang berarti tingkat korelasi kuat antara variabel tingkat kecemasan dengan motivasi kerja. Hasil nilai signifikansi untuk penelitian ini adalah $p=0,001(\alpha<$ $0,05)$ yang dapat diartikan ada hubungan yang signifikan antara tingkat kecemasan dengan motivasi 
kerja. Dapat disimpulkan dari hasil penelitian ini adalah semakin tinggi tingkat kecemasan yang dialami responden semakin rendah tingkat motivasi kerja responden tersebut dan semakin ringan tingkat kecemasan responden semakin tinggi motivasi kerjanya. Donsu (2017:234-236) mengungkapkan bahwa motivasi dapat dibangun dengan dua metode yaitu motivasi yang diberikan secara langsung kepada setiap individu untuk memenuhi kebutuhan serta kepuasannya seperti pujian, penghargaan, tunjangan hari raya dan motivasi tidak lansung seperti fasilitas-fasilitas yang mendukung serta menunjang gairah kerja, sehingga lebih bersemangat dalam bekerja, misalnya mesin yang baik, ruang kerja yang nyaman dan sebagainya. Hal ini didukung pernyataan sebagian besar responden bahwa faktor tunjangan penghasilan serta keamanan sangat berpengaruh dengan motivasi kerja karena tunjangan yang tidak sesuai dan kondisi kemanan lingkungan yang belum memadai menimbulkan rasa cemas dan beban pikiran sehingga menurunkan semangat atau motivasi untuk bekerja. Apabila kebutuhan dasar dan rasa aman sulit diperoleh, pemenuhan kebutuhan tersebut akan mendominansi tindakan seseorang dan motif-motif yang lebih tinggi akan menjadi kurang signifikan. Hal ini sejalan dengan penelitian yang dilakukan oleh Setiawan dan Bodroastuti (2012) dengan judul "Pengaruh Karakteristik Individu dan Faktor-faktor Pekerjaan terhadap Motivasi (Studi Pada Karyawan CV. Bintang Timur Semarang" dengan hasil penelitian menunjukkan bahwa faktor-faktor pekerjaan berpengaruh terhadap motivasi kerja dengan $p=0,007$. Faktor-faktor pekerjaan dalam penelitian ini menggunakan faktor yang berasal dari dalam perusahaan yang berasal dari kondisi fisik dan tempat dimana karyawan bekerja yang meliputi gaji dan benefit yang diterima, kondisi pekerjaan seperti jam kerja, lingkungan, fisik dan sebagainya, sedangkan faktor dalam pekerjaan meliputi: sifat pekerjaan, rancangan tugas, pemberian pengakuan terhadap prestasi, tingkat atau besarnya tanggung jawab yang diberikan perusahaan dan adanya perkembangan dan kemajuan dalam pekerjaan. Seperti juga penelitian yang dilakukan oleh Siregar dan Hardjo (2013) dimana variabel kecemasan kematian secara signifikan berpengaruh terhadap motivasi kerja karyawan ODHA, ini terlihat dari nilai signifikan 0,03 lebih kecil dari 0,05 dan hasil thitung $(-3,117)<t_{\text {tabel. }}$. Hal ini menunjukkan bahwa semakin rendah kecemasan kematian maka semakin tinggi motivasi kerja karyawan ODHA.

\section{KESIMPULAN}

1. Hasil penelitian menunjukkan 26 responden $(81,25 \%)$ mempunyai tingkat kecemasan ringan, 5 responden $(15,62 \%)$ mempunyai tingkat kecemasan sedang dan 1 responden $(3,13 \%)$ mempunyai tingkat kecemasan berat. Sebagian besar responden yaitu sejumlah 18 orang $(56,25 \%)$ mempunyai motivasi kerja tingkat sedang, 11 orang $(34,38 \%)$ mempunyai motivasi kerja tinggi dan paling sedikit 3 responden $(9,37 \%)$ mempunyai motivasi kerja rendah.

2. Hasil uji menggunakan Rank Spearman program SPSS versi 18.0 dengan $\alpha=1 \%(0.01)$ diperoleh angka koefisen korelasi $(r)=0,552$. Hasil nilai signifikansi untuk penelitian ini adalah 0,001 ( $\alpha<0,05)$ yang dapat diartikan ada hubungan yang signifikan antara tingkat 
kecemasan dengan motivasi kerja.

\section{SARAN}

1. Berdasarkan hasil penelitian, terdapat beberapa indikator yang dianggap belum optimal dan menimbulkan rasa cemas seperti tunjangan dan kondisi lingkungan kerja yang belum dirasakan aman oleh perawat, sehingga disarankan kepada pihak pimpinan rumah sakit untuk dapat memberikan motivasi kepada karyawan untuk dapat bekerja dengan baik dengan memberikan fasilitas dan tunjangan yang sesuai untuk karyawan serta jaminan kesehatan dan keselamatan yang memadai.

2. Bagi perawat diharapkan dapat memiliki komitmen yang tinggi pada pekerjaannya dan hendaknya lebih meningkatkan motivasi kerja agar dapat menghasilkan pelayanan yang berkualitas sebagai pelaksana tindakan keperawatan profesional.

\section{DAFTAR PUSTAKA}

Aswat, Bustanul. 2010. Faktorfaktor yang Berhubungan dengan Motivasi Kerja Perawat di Unit Rawat Inap di RSUD Puri Husada Tembilahan Kabupaten Inderagiri Hilir Riau. Tesis Pascasarjana. Universitas Indonesia, Jakarta. Di akses 8 Maret 2019.

Cahyani, Intan Dwi, Ida Wahyuni dan Bina Kurniawan. 2016. Faktor-Faktor Yang Berhubungan Dengan Motivasi Kerja Pada Perawat Rumah Sakit Jiwa (Studi Pada Bangsal Kelas III RSJD Dr.Amino Gondohutomo Provinsi Jawa Tengah). Jurnal Kesehatan Masyarakat. Volume II.
Fakultas Kesehatan

Masyarakat UNDIP.

Semarang. Diakses pada tanggal 27 Oktober 2018.

Donsu, Jenita Doli Tine. 2017. Psikologi Keperawatan.

Pustaka Baru Press, Yogyakarta.

Elvia. 2013. Hubungan

Pengetahuan dengan

Perilaku Penggunaan Alat Pelindungan Diri (APD) pada Mahasiswa Pendidikan Profesi Ners Program Studi IImu Keperawatan Fakultas Kedokteran Universitas Syiaah Kuala Aceh. Universitas Kuala Aceh. Aceh. Diakses pada tanggal 7 November 2018.

Efstathiou, G., et al. (2011). Factors Influencing Nurses' Compliance with Standard Precautions in Order to Avoid Occupational Exposure to Microorganisms : a Focus Group Study. BMC Nursing. Diakses pada tanggal 27 Oktober 2018.

Hawari, Dadang. 2011. Manajemen Stres, Cemas dan Depresi. Balai Penerbitan FKUI, Jakarta.

Kozier, Barbara, et al. 2010. Buku Ajar Fundamental Keperawatan: konsep, proses dan praktik. Edisi VII. Alih Bahasa Pamilih Eko Karyani. EGC, Jakarta.

Lestari, R., T. A. Wihastuti dan B. F. Rahayu. 2013. Hubungan Tingkat Kecemasan Dengan Tingkat Kemandirian Activities Of Daily Living (Adl) Pada Lanjut Usia Di Panti Werdha. Jurnal IImu Keperawatan. Universitas Brawijaya. Malang. Diakses 8 Pebruari 2019.

Prawiharjo, Sarwono. 2014. IImu Kebidanan. Bina Pustaka, Jakarta 
Priyoto. 2015. Nursing Intervention Classification Dalam Keperawatan Gerontik. Salemba Medika, Jakarta.

Ramadini, Indri dan Erni Jasmita. 2015. Hubungan Motivasi dengan Kinerja Perawat Pelaksana di Ruangan Rawat Inap RSUD Dr. Rasidin Padang. Ners Jurnal Keperawatan. Volume 11. Padang. Diakses tanggal 28 Oktober 2018.

Rizky, Denizia dan Tri Wulida Afrianty. 2018. Pengaruh Beban Kerja Terhadap Stres Kerja Dengan Work Life Balance Sebagai Variabel Intervening (Studi Pada Dinas Sosial Provinsi Jawa Timur Surabaya). Jurnal Administrasi Bisnis. Volume 61. Surabaya. Diakses 8 Maret 2019.

Rochman, Kholil Lur. 2010. Kesehatan Mental. Fajar Media Press, Purwokerto.

Setiawan, Andi dan Tri Bodroastuti. 2012. Pengaruh Karakteristik Individu dan Faktor-Faktor Pekerjaan Terhadap Motivasi (Studi Pada Karyawan CV. Bintang Timur Semarang). Jurnal Kajian Akuntasi dan Bisnis. Semarang. Diakses tanggal 8 Maret 2018.
Siregar, Indo Mora dan Suryani Hardjo. 2013. Hubungan Kecemasan Kematian Dan Dukungan Sosial Terhadap Motivasi Kerja Karyawan Odha (Orang Dengan HIVAIDS). Jurnal Analitika. Universitas Medan Area. Diakses tanggal 12 Pebruari 2019.

Sobur Alex. 2011. Psikologi Umum. Pustaka Setia, Bandung

Sucipto, Cecep Dani. 2014. Keselamatan dan Kesehatan Kerja. Gosyen Publishing, Yogyakarta.

Widodo, et al. 2017. Analisis Faktor Tingkat Kecemasan, Motivasi Dan Prestasi Belajar Mahasiswa. Jurnal Taman Cendikia. Yogyakarta. Diakses tanggal 30 Januari 2019.

Wijayanti, Dea Woro. 2017. Hubungan Antara Kecemasan Dengan Prestasi Kerja Karyawan PT. Kusumahadi Santosa Karanganyar. Universitas Muhammadiyah Surakarta. Diakses tanggal 26 Oktober 2018.

${ }^{1}$ Dosen AKPER Panti Kosala

Surakarta

${ }^{2}$ Staf RSUD dr. Soeratno Gemolong Sragen 